\title{
The Developmment of the Assessment's Instrument Based on Higher Order Thinking Skills To Measure Dimension of Persuasive Text Skills on Students Of Class VIII in Junior High School Muhammadiyah 7 Medan
}

\author{
Indah Fajarini ${ }^{1}$, M. Oky Fardian Gafari ${ }^{2}$, Abdurahman Adisaputera ${ }^{2}$ \\ ${ }^{I}$ Master Student in State University of Medan (Unimed), Indonesia \\ ${ }^{2}$ Lecturer in State University of Medan (Unimed), Indonesia \\ indahfajarini54@gmail.com
}

\begin{abstract}
This research deals with the development of the assessment's instrument based on higher order thinking skills to measure dimension of persuasive text skills on students of class VIII in junior high school Muhammadiyah 7 Medan. The type of this research is research and development. The sampling technique used in this study is purposive sampling technique. The result shows that the process of developing assessment instruments is based on Higher Order Thinking Skills on Indonesian language subjects in junior high school Muhammadiyah 7 Medan through 4 stages, there are: (1) Preparation of Tests, (2) Selection of Media (3) Selection of Formats (4) Initial design results by composing stories board, make layouts by paying attention to the color and composition and fill the layout with activities in the form of, activity 1 contains the mapping of KI, KD, and indicators, as well as 10 multiple choice questions and 5 description questions. Activity 2 contains the mapping of KI, KD, and indicators as well as 15 multiple choice questions and 5 description questions and scoring, answer keys, glossary and bibliography.
\end{abstract}

Keywords : Assessment's Instrument; Higher Order Thinking Skills; Students

\section{Introduction}

Indonesian language learning in the 2013 curriculum is text oriented. For class VIII students, one of the texts studied is Persuasive text. Based on books of Indonesian Language class VIII (2017: 176) Persuasive texts are texts that contain invitations or persuasions. From various branches of knowledge in learning Indonesian Language and Literature in Middle School, most students still have difficulty understanding the Persuasive text material. In fact, the questions in Persuasive text material have a lot to do with the application of argumentation and creativity in everyday life. These questions related to creativity need to be developed because they can train students' higher thinking skills (Higher Order Thinking Skills).

Students' understanding of Persuasive texts at school is still low. Why is that? In general, Persuasive text learning is done in a monotonous and less interesting manner. Students are not invited to explore and analyze the text of the Persuasive, but merely read and study the text of the Persuasive from its surface. Learning the Persuasive text in the class has not touched on the students' desire for higher-order thinking, but it is a form or picture that they get just to remember.

This is in line with the results of observations conducted by Nur Hady Eko Setiawan (2014) which stated that the results of the study showed that the form and type of language errors in persuasive essays of class X students at Boyolali 2 High School included: (a) language errors in spelling as much as $45.6 \%$, (b) language errors in the morphology field as much as $17.8 \%$, (c) language errors in semantic fields as much as $14.8 \%$, and (d) language errors in the syntactic field as much as $21.8 \%$. Furthermore, the frequency of the most common language errors found in this study is the spelling field error. The causes of language errors in students' 
persuasive essays are caused by internal factors, including: (a) low motivation, (b) potential students, (c) lack of exercise frequency, and external factors, including: (a) environment, (b) teacher, (c) mother tongue.

In addition, the assessment only relies on aspects of knowledge and concepts but not entirely on skills. This illustrates that the high level of thinking ability of Indonesian children is scientifically considered still low so it is difficult to know or measure the dimensions of student factual, conceptual, procedural, and metacognitive knowledge.

Based on the results of the interview on Monday, July 16, 2018 for Indonesian Language subject teachers in Muhammadiyah 7 Medan Middle School, it was found that teachers were still less capable of conducting assessments using relevant instruments. The assessment is carried out by the teacher on the knowledge aspect of answering the questions that have been tested before, making assignments and homework such as making notes, besides that it is also only done through observation when the learning process takes place without any clear references or grids. Considered to have made an assessment. Such assessment activities actually cannot be categorized as assessment

The results of preliminary observations also show that the problems that occur in schools, especially in Class VIII Muhammadiyah 7 Medan Middle School are cognitive assessment instruments used in the form of questions that tend to test the memory aspect more, while the questions that train students' high-level thinking skills have not widely available. This is stated based on the results of item analysis about UTS Indonesian language subjects made by teachers totaling 35 questions classified as quite poorly done by researchers using the ANATES version 4.0.10 application found in table 1 .

Table. 1 Analysis of UTS Questions in Indonesian Language subjects in Class VIII-4 of 7 Muhammadiyah Middle School in Medan

\begin{tabular}{|l|l|l|l|}
\hline Analysis & Criteria & Number of questions & Percentage \\
\hline \multirow{2}{*}{ Validity } & Valid & 10 & $28 \%$ \\
\cline { 2 - 4 } & Invalid & 25 & $71 \%$ \\
\hline \multirow{3}{*}{ Difficulty level } & Easy & 18 & $51 \%$ \\
\cline { 2 - 4 } & Medium & 13 & $37 \%$ \\
\cline { 2 - 4 } & Hard & 4 & $11 \%$ \\
\hline \multirow{3}{*}{$\begin{array}{l}\text { Distinguishing } \\
\text { power }\end{array}$} & Good & 2 & $5 \%$ \\
\cline { 2 - 4 } & Enough & 6 & $17 \%$ \\
\cline { 2 - 4 } & Ugly & 27 & $77 \%$ \\
\hline
\end{tabular}

Assessment based on higher order thinking skills to measure the dimensions of knowledge students can use the form of subjective tests and objective tests. Subjective testing is a description form test. Description form tests are items that contain questions or assignments that answer or work on the question must be done by expressing the thoughts of the test takers. The distinctive feature of the description test is that the answer to the question is not provided by the question compiler, but must be prepared by the test participant. Item type description, consisting of questions and answers must be fully considered by the test participant. Therefore, the skill of expressing thoughts in written form will have a large contribution in answering questions. This form of question is very good for measuring learning outcomes at the level of analysis, evaluation, and creation. 


\section{Literature Review}

\subsection{Assessment Instruments}

According to Minister of Education and Culture No. 104 of 2014 the instrument is a tool that meets academic requirements, so that it can be used for measuring instruments to measure a measuring object or collect data about a variable. Meanwhile, assessment instruments are tools used to assess student learning outcomes, for example tests and attitude scales. Assessment is part of the daily learning process carried out continuously. Assessment is the most important part of learning, because it is the most effective strategy to help identify students in learning. The results of the assessment are the initial process before making a decision about the next steps in improving the ability to understand student learning (Amnie, 2016: 59).

According to Abosalem (2016: 3) assessment is the collection of information to make evaluative decisions, and used in relation to the test. This is in line with Haertel's opinion in Mangiante (2013: 222) assessment is a tool to measure the extent to which students have improved their learning based on standards. Based on RI Government Regulation No. 32 of 2013 concerning the assessment standard explained that assessment is the process of gathering and processing information to determine the achievement of student learning outcomes. Assessment is not just the collection of student data, but also processing to obtain an overview of the learning process and results. Assessment is not just about giving students questions and then completing, but the teacher must follow up for learning purposes.

According to I.S.P. Nation and Macalister (2010: 120) Assessment is a major source of information for evaluation of a course and thus its gradual improvement. Assessment also contributes to the teacher and learners' sense of achievement and thus is important for motivation. The statement means "Assessment is the main source of information for school evaluation and thus the increase can be gradual. Assessment also contributes significantly to the achievement of teachers and students in a school and is therefore important for motivation.

Mangiante (2013: 222) assessment is a tool to measure the extent to which students have improved their learning based on standards.

Based on RI Government Regulation No. 32 of 2013 concerning the assessment standard explained that assessment is the process of gathering and processing information to determine the achievement of student learning outcomes. Assessment is not just the collection of student data, but also processing it to obtain an overview of the learning process and results. Assessment is not just about giving students questions and then completing, but the teacher must follow up for learning purposes. Assessment (assessment) is a statement based on a number of facts to explain the characteristics of a person or something (Griffin and Nix, 1991 in the Ministry of Education, 2004: 10).

\subsection{Persuasive Text}

The term Persuasive is the transfer of Persuasifon words in English. The form of the word Persuasifon is derived from the word to persuade which means persuading or convincing. So, Persuasive essays are essays that contain exposures of persuasion, empowerment, or impotence that can arouse the enthusiasm of the reader to believe and obey the implicit and explicit appeal conveyed by the author. In other words, Persuasive dealing with problems influences others through language. 
According to (Kusmana, 2014: 86) Persuasiff text is a text that contains ideas that aim to convince readers and invite readers to do something as expected by the author. The author intends to invite readers to do or do something as expected. There are many activities around us that must be done with convincing invitations to influence the expected goals.

Nursisto (1999: 45) says that Persuasion or appeal is a type of essay which in addition contains reasons from evidence or facts, also contains invitations or appeals for readers to accept and follow the opinions or willingness of the author.

Persuasive is an essay that is intended to influence the attitudes and opinions of readers about something that the author conveyed (Yunus and Suparno, 2004: 1.12). Persuasive essays aim to convince readers to do something the author wants. Like argumentation, Persuasion also uses evidence or facts. It's just that, in Persuasive the evidence is used as needed or sometimes manipulated to give rise to readers' trust that what the author conveyed is true.

Based on the opinion above it can be concluded that Persuasive text is a type of text which contains a notification that aims to convince or invite someone to do something that is desired by the author to the reader.

According to Syamsuddin (2009: 23), there are several characteristics of Persuasive text as follows.

1. Must create the trust of the listener / reader;

2. Starting from the stand that the human mind can be changed;

3. Must create conformity through trust between the speaker / writer and the one invited to speak or the author;

4. Must avoid conflict so that trust is not lost and goals are achieved and;

5. There must be sufficient facts and data.

\subsection{Definition of Higher order thinking skills}

Higher order thinking skills in Indonesian are known as high-level thinking skills. Highlevel thinking skills students think patterns by relying on the ability to analyze, create, and evaluate all aspects and problems. According to Ernawati (2017: 196-197), high-level thinking or Higher order thinking skills (HOTS) is a way of thinking that no longer only verbalizes verbally but also means the essence of what is contained, among other things, to be able to interpret integralistic thinking by analysis, synthesis, association to draw conclusions towards the creation of creative and productive ideas.

Meanwhile according to Cambridge English Teaching Knowledge Test, The University of Cambridge (2015) in Arifin's book (2018: 17), Higher order thinking skills are cognitive skills such as analysis and evaluation that can be taught by teachers to their students. These skills include thinking about something and making decisions about things, solving problems, thinking creatively, and thinking about benefits (positive things) and losses (negative things) of something.

Higher Order Thinking Skills (HOTS) is a thought process that involves mental activity in an effort to explore complex, reflective and creative experiences that are consciously carried out to achieve goals, namely acquiring knowledge that includes the level of analytical, synthesis, and evaluative thinking. This ability to think will arise when individuals or students are faced with problems that they have not met before. At present the theories that develop about Higher order thinking skills are more focused on how these skills are learned and developed. Appropriate teaching strategies and learning environments that can facilitate students' thinking skills are important factors for achieving this approach. Like student 
perseverance, self-monitoring, and open thinking and flexible attitude (Rofiah, et.al., 2013: 17).

According to Krulik \& Rudnick (1999: 138) thinking ability consists of four levels, namely: memorization (recall thinking), basic thinking (basic thinking), critical thinking (creative thinking) and creative thinking (creative thinking). Memorizing is the lowest level of thinking. These skills are almost automatic or reflexive in nature. The level of thinking is hereafter referred to as basic skills. These skills include the skills of understanding concepts. Critical thinking is thinking that checks, connects, and evaluates all aspects of a situation or problem. The last level is creative thinking that is original and reflective. The results of these thinking skills are complex. The activities carried out include uniting ideas, creating new ideas, and determining their effectiveness. Creative thinking also includes the ability to draw conclusions that usually bring forth new results.

\section{Research Methods}

The study was conducted at 7th Muhammadiyah Middle School in Medan. This research was conducted in the even semester of the 2018/2019 academic year. The subjects in this study were grade VIII students at 7th Muhammadiyah Middle School in Medan. While the object of this research is the teacher and the validity expert team, namely material experts and evaluation experts. The population in this study were all students of class VIII at 7th Muhammadiyah Middle School, amounting to 140 students.

The sampling technique used in this study was purposive sampling technique. According to Sugiyono (2014: 24) purposive sampling is a sampling technique with certain considerations. The number of samples is determined by the researcher according to the purpose.

This type of research is research and development or Research and Development ( R \& D). This research is called $\mathrm{R} \& \mathrm{D}$, by adopting eight steps of $\mathrm{R} \& \mathrm{D}$ research according to Sugiyono (2014: 137). The steps are: (1) Stage of seeing potential and problems, (2) Stage of gathering information and study of literature, (3) Stage of designing products, (4) Stage of validating designs, (5) Stage of revising designs, (6) The stage of testing the product, (7) The stage of revising the product that has been tested (8) The stage of testing the use of the revised product. This product development will be used to find out students' cognitive abilities in certain basic competencies. This study develops assessment instruments based on Higher Order Thinking Skills to measure the dimensions of knowledge in students' persuasion texts.

\section{Discussion}

An instrument is a tool used to collect and collect information. One tool that can help teachers in collecting data and collecting learning information is an assessment instrument. Permendikbud Number 104 of 2014 states that assessment instruments are tools used to assess student learning outcomes, for example: tests, and attitude scales. Thus the assessment instrument must describe the competencies that students will achieve, presented in good and interesting language. Assessment instruments can be in the form of test and non-test instruments, instruments aim to express values and beliefs, both positive and negative (Ismet and Hariyanto. 2014: 196).

The assessment instruments developed in this study are assessment instruments based on Higher Order Thionking Skills in the form of tests, meaning the assessment instruments are 
filled with questions on Higher Order Thinking Skills. Questions on Higher Order Thinking Skills are measurement instruments used to measure high-level thinking skills, namely the ability to think that is not just a recall. Restate, or refer without doing processing (recite). Nonetheless, the Higher Order Thinking Skills based questions do not mean that the problem is more difficult than the problem of recall.

Based on the results of the teacher needs analysis of assessment instruments based on Higher Order Thinking Skills, it shows that teachers need valid, effective and practical assessment instruments and students' needs for Higher Order Thinking Skills based assessment instruments because the knowledge of Indonesian students varies. But in general the high-level thinking skills of students have never been traced either by teachers or other researchers. Students also rarely get questions that can hone students' high-level thinking skills. In addition, the results of the needs analysis also show that so far the assessment instruments used by teachers have been only assessment instruments that have been published by the government or the results of cooperation at the time of the GFC without any other handbook. The teacher states that the availability of other assessment instruments will help students understand persuasive text material, especially helping students solve the problems they face. Based on the explanation above, it can be concluded that the assessment instruments used so far in schools have not been in accordance with the needs of teachers and students. Therefore, the development of Higher Order Thinking Skills based assessment instruments will certainly help students in learning persuasive texts.

The choice of the Higher Order Thinking Skills in developing this assessment instrument aims to make students not only understand persuasive texts when using these assessment instruments, but also at the same time understand the problems students will face in learning. Viewed from the knowledge dimension, generally the Higher Order Thinking Skills problem measures the dimensions of metacognitivity, not just measuring factual, conceptual or procedural dimensions. Metacognitive dimensions describe the ability to connect several different concepts, interpret problem solving (problem solving), choose problem solving strategies, find (discovery) new methods, argue (reasoning), and make the right decisions.

Based on the results obtained from the discussion above, the assessment instruments based on Hogher Order Thinking Skills are very relevant to students' learning needs. Because the assessment instruments were developed in addition to being adapted to the needs of students, this assessment instrument was also presented with contextual problems (linked to student life) and the assessment instruments prepared were in accordance with the 2013 curriculum in Indonesian language syllabus.

\subsection{Feasibility of Assessment Instruments}

The feasibility of evaluating based on Higher Order Thinking Skills was developed with the aim of optimizing students' high level thinking skills. Related to the validity of the product produced must have a validity level of the product, namely, Otto (2010: 348) explains that validity refers to the idea that the right one actually measures what is intended to be measured. This means that various tasks are carefully selected to represent the basis of important developments and behavior.

The Higher Order Thinking Skills based assessment instrument that has been developed has fulfilled the requirements as a learning assessment tool for decent junior high school students according to Badru Zaman (2006: 7-8) that is in accordance with the applicable education program so that the making of Higher Order Thinking Skills based assessment instruments such as test, media selection, format selection, and initial design results. 
This development research resulted in Higher Order Thinking Skills-based assessment instruments that were appropriate for use in learning assessment. Product feasibility is obtained by using a questionnaire instrument in which there are material assessments (content feasibility, presentation feasibility, language assessment) and evaluation feasibility.

The first step carried out in this study was to conduct a preliminary study which was started by conducting a needs analysis. Needs analysis is carried out to obtain information about assessment instruments that are appropriate to the needs. The second stage, designing and designing assessment instruments that will be developed based on data that has been obtained from the initial stage. The third stage is to validate the assessment instruments that have been developed to material experts and evaluation experts to obtain validity of the assessment instruments.

The fourth stage, the assessment instrument that has been validated, then revisions based on the results obtained from material experts and evaluation experts. Next, validate the Indonesian language teachers to obtain an Indonesian language teacher response to the assessment instruments based on the Higher Order Thinking Skills that have been developed. The fifth stage, conduct individual trials of assessment instruments to students to find out student responses to assessment instruments that have been developed. The sixth stage, after getting the results of individual trials, the assessment instrument is revised back in accordance with the results obtained, if it has received a good response, the next stage is carried out. The seventh stage, conducting limited group trials with a total of 9 students. At this stage, because there are no suggestions for improvement from students, then proceed to the next stage. The eighth stage, conducting limited group trials with 35 students.

The results of the validation obtained are described as follows:

1. The results of the material expert validation are divided into three aspects of assessment, namely, feasibility of content, feasibility of presentation, and feasibility of language. The results of the assessment on the aspect of content eligibility are obtained by the criteria "very valid" The results of the assessment on the aspects of the feasibility of presentation are obtained as "very valid" criteria. The results of the assessment of language assessment are obtained by "very valid" criteria. The total results of the assessment of the three aspects are obtained by the criteria of "very good".

2. The evaluation validation results are divided into two assessment aspects, namely, validation of multiple choice assessment instruments and instrument validation. The results of the assessment on the validation of multiple choice instruments are obtained in the "very valid" criteria. The results of the evaluation on the description instrument validation are obtained from the "very valid" criteria. The total results of the assessment of both aspects are obtained from the "very valid" criteria.

3. Results of assessments conducted by Indonesian language teachers on assessment instruments based on Higher Order Thinking Skills obtained in the criteria of "very practical".

Based on the results obtained from the series of stages of development of Higher Order Thinking Skills based assessment instruments declared feasible according to the results of the validation of material experts, evaluation experts, and teacher responses to the criteria "very practical".

\subsection{Quality of Assessment Instruments based on Higher Order Thinking Skills}

Akker (1999: 10) states that practicality in development research is "practically referring to the extent to which the user adheres to attractive and preferred interventions in normal 
conditioning. Practicality refers to the level that users consider interventions can be used and preferred under normal conditions. This means that the practicality of the product is easy and can be used by teachers and students. In each stage of the trial, each student will assess the assessment instruments based on Higher Order Thinking Skills by filling out the student response questionnaire in which there are 12 indicators of assessment.

In this study, the researchers conducted three stages of the trial, namely the stages of individual trials, small groups and field trials. At the stage of individual trials involving 3 students, the percentage was $81 \%$, which was in the excellent category. Based on the results of the student response analysis, Sinaga (2007) states that to determine the achievement of learning objectives in terms of student responses, if the number of students who give a positive response is greater or equal to $81 \%$ of the number of subjects studied for each trial. So from that the assessment instruments developed were classified as very good. Furthermore, the researcher continued the small group trial involving 9 students with the percentage gain in the excellent category. Then the researchers conducted a field trial involving 35 students getting the percentage into a very good category.

At this stage of the field test, researchers also tested the content validity of assessment instruments based on Higher Order Thinking Skills to determine the quality of the instruments developed.

a. Based on the results of the trial assessment instrument based on Higher Order Thinking Skills obtained the average level of validity of multiple choice questions 0.57 and description of 0.573 in activity 1 . In activity 2 the average level of validity was obtained by multiple choice questions of 0.56 and description of 0.468 .

b. Based on the results of the reliability analysis instrument for the assessment of high-level thinking using the ANATES version 4.10 application it is known that Higher Order Thinking Skills-based assessment instruments to measure the dimensions of student knowledge are classified as reliable in multiple choice questions at high interpretations and a description of activities in activities 1. In activities 2 levels of reliability of multiple choice questions are at a high interpretation and in the tests description is at a moderate interpretation. Thus, the assessment instruments that have been developed can be trusted and provide the same results if these tests are carried out on different subjects or places or conditions.

c. Based on the results of item analysis in terms of the level of difficulty of the instrument for assessing high-level thinking skills in activity 1 it is known that out of the 10 questions tested were at the medium category with an average difficulty level of 0.481 and there were 1 question with easy categories, 9 questions with moderate categories, while for the description questions tested 5 questions in the medium category with an average difficulty level of 0.422 in the medium category. In Activity 2 it was found that out of the 15 questions tested were at the level of the medium category with an average difficulty level of 0.772 and there were 2 questions with easy categories, 12 questions with moderate categories, and 1 question with difficult categories. Whereas for the description questions tested there are 5 questions in the medium category with a mean difficulty level of 0.42 in the medium category. Problems with easy categories show that the assessment instruments tested are relatively easy to measure for high-level thinking skills for students who have high, medium and low thinking skills. The questions in the medium category show that the assessment instruments being tested are classified as moderate for students with high, medium level thinking skills. Problems with difficult categories show that only a small 
percentage of students can do those well and difficult questions require deeper understanding.

d. Based on the results of the analysis of the items in terms of the differentiation of assessment instruments based on Higher Order Thinking Skills in Activity 1, it was found that out of 10 multiple choice questions tested there were no items classified as very bad and not good, 5 items with moderate categories, 3 items questions with good categories, and 2 items with very good categories with the results of the average differentiator 0.62 with good categories. And from the 5 item description there are 4 items with a medium category, 1 item with a good category with the results of the average distinguishing score of the instrument 0.38 with the medium category. In Activity 2 it was found that out of 15 multiple choice questions tested there were no items classified as very bad and not good, 7 items with moderate categories, 6 items with good categories, and 2 items with very good categories with average results. -difference rate of 0.95 with a very good category. And from the 5 description items there are 1 item with a very good category, 2 items with a good category, and 2 items with a moderate category with the results of the average distinguishing instruments of the assessment 0.476 with the medium category.

\section{Conclusion}

The process of developing assessment instruments is based on Higher Order Thinking Skills on Indonesian language subjects in junior high school Muhammadiyah 7 Medan through 4 stages, there are: (1) Preparation of Tests, (2) Selection of Media (3) Selection of Formats (4) Initial design results by composing stories board, make layouts by paying attention to the color and composition and fill the layout with activities in the form of, activity 1 contains the mapping of KI, KD, and indicators, as well as 10 multiple choice questions and 5 description questions. Activity 2 contains the mapping of KI, KD, and indicators as well as 15 multiple choice questions and 5 description questions and scoring, answer keys, glossary and bibliography.

\section{References}

.Abdurrahim. 2011. Pengembangan Model Pembelajaran Berbasis Proyek Untuk Meningkatkan Kompetensi Siswa Pada Pembelajaran Teknologi Informasi dan Komunikasi (TIK) di Madrasah Aliyah Kota Bima. (Thesis). Curriculum Development Department of SPS UPI. Not Published.

Abosalem, Yousef. 2016. Assessment Techniques and Students Higher-Order Thinking Skills. International Journal of Secondary Education, 4 (1): 1 - 11. http://www.sciencepublishinggroup.com/j/ijsedu. Accessed on 1 August 2016.

Akbar, S. 2013. Instrumen Perangkat Pembelajaran. Bandung: PT. Remaja Rosdakarya.

Amnie, Erlida. 2016. Summative Assessment Design through the PjBL to Improve Students' Higher-Order Thinking Skills. Makalah disajikan dalam International Conference in Education Research and Evaluation, UNY. https://pps.uny.ac.id/sites/pps.uny.ac.id/files/Prosiding\%20ICERE\%202016-ilovepdfcompressed\%20(1).pdf. Accessed on 1 September 2016.

Anwar, Syafri. 2009. Penilian Berbasis Kompetensi. UNP Press, Padang.

Arifin, Zainal. 2009. Evaluasi Pembelajaran. PT Remaja Rosdakarya, Bandung. 
Arikunto, Suharsimi. 2012. Dasar-Dasar Evaluasi Pendidikan. Bumi Aksara, Jakarta.

Barnett, J. E and Francis, A.L. 2012. Using higher order thinking questionsto foster critical thinking: a classroom study. Educational Psychology: An International Journal of Experimental Educational Psychology. Vol. 3, No. 2, p: 209

Borg, W. R. \& Gall, M.D. 1983. Educational researcher: An introduction, (7thed.). United States : Pearson education, Inc

Brookhart, S. M. 2010. How to Assess Higher order thinking skills in Your Classroom. Alexandria: ASCD

Dewi, Nastitisari. 2016. Analisis Kemampuan Berpikir Kompleks Siswa Melalui Pembelajaran Berbasis Masalah Berbantuan Mind Mapping. Journal of Edu-Sains. Vol 8 No 1(online). Available in http://journal.uinjkt.ac.id/index. php/edusains. Accessed on 20 April 2017.

Departemen Pendidikan Nasional. 2004. Kerangka Dasar Kurikulum 2004. Jakarta

Ernawati, L. 2017. Pengembangan High Order Thinking (HOT) Melalui Metode Pembelajaran Mind Banking Dalam Pendidikan Agama Islam. PROCEEDINGft, 189. Accessed in hhtp://bit.ly/2BmXOJU on 20 November 2017.

Harjanto. 2006. Perencanaan Pembelajaran. Jakarta: Rineka Cipta.

Indonesia nomor 53 tahun 2015, tentang Penilaian hasil belajar Pendidik pada pendidikan dasar dan pendidikan menengah.

Kadir, Abdul. 2015. Menyusun dan Menganalisis Tes Hasil Belajar. Jurnal Alta'dib. Vol 8 No 2 (online). Available in http://ejournal.iainkendari.ac.id Accessed on 16 December 2016.

Kemendikbud. 2013. Peraturan Pemerintah No.32 Tahun 2013 tentang Standar Penilaian Nasional Pendidikan. Kementrian Pendidikan dan Kebudayaan, Jakarta. . 2014. Permendikbud Nomor 104 Tahun 2014 tentang Penilaian Hasil Belajar Oleh Pendidik Pada Pendidikan Dasar dan Pendidikan Menengah. Kementrian Pendidikan dan Kebudayaan RI, Jakarta.

2016. Permendikbud Nomor 23 Tahun 2016 tentang Penilaian Hasil Belajar Oleh Pendidik Pada Pendidikan Dasar dan Pendidikan Menengah. Kementrian Pendidikan dan Kebudayaan RI, Jakarta.

Kementerian Pendidikan dan Kebudayaan Edisi Revisi 2016. Bahasa Indonesia SMP/MTs. Kelas VIII.

Krathwohl, D. R.2002. A revision of Bloom's Taxonomy: an overview - Theory Into Practice, College of Education: The Ohio State University Pohl.(Available in www.purdue.edu/geri Accessed on 22 February 2016)

Krulik, S \& Rudnick. 1999. Innovative Taks to Improve Critical and Creative Thinking Skills. Develoving Mathematical Raesoning in Grades K-12. pp.138-145.

Kusaeri. 2014. Acuan dan Teknik Penilaian Proses dan Hasil Belajar dalam Kurikulum 2013. Yogyakarta: Ar-Ruzz Media.

Kusmana, Suherli. 2014. Kreativitas Menulis. Yogyakarta: Ombak.

Kusnawa, Wowo Sunaryo. 2012. Taksonomi Kognitif. Bandung: PT. Remaja Rosdakarya.

Laily, Nur Rochmah. 2013. Analisis Soal Tipe Higher Order Thinking Skill (Hots) Dalam Soal Un Kimia Sma Rayon B Tahun 2012/2013. Journal of unswagati. Vol 9 No 1. Available in jurnal.unswagati.ac.id/index.php /Euclid/article /download/323/203 (online). Accessed on 20 April 2017.

Lewy, Zulkardi, \& N Aisyah. 2009. Pengembangan Soal untuk Mengukur Kemampuan Berpikir Tingkat Tinggi Pokok Bahasan Barisan dan Deret Bilangan di Kelas IX Akselerasi SMP Xaverius Maria Palembang. JOURNAL OF Mathematics Education (3). Vol: 8, No. 2, p: 15-28. 
Malik, A., Chandra, E. \& Agus S. 2015. Deskripsi Kebutuhan Hots Assessment Pada Pembelajaran Fisika Dengan Metode Inkuiri Terbimbing. Prosiding Seminar Nasional Fisika, Vol. IV (3) 1-4 http:/ /www.snfunj. ac.id/files/6414/4620/6494/SNF2015-III-14.pdf. (Accessed on 1 August 2016).

Mangiante, Elaine Silva. 2013. Planning Science Instruction for Critical Thinking: Two Urban Elementary Teachers' Responses to a State Science Assessment. Journal Education Science, Vol 3: 222-258. www.mdpi.com/journal/ education. Accessed on 12 November 2015.

Mardapi, Djemari. 2008. Teknik Penyusunan Instrumen Tes dan Nontes. Mitra Cendekia, Yogyakarta.

Matondang, Zulkifli. 2009. Validitas Dan Reabilitas Suatu Instrumen Penelitian. Junal Taburasa PPS Unimed. Vol 6 No 1 (online). Available http://ejournal.unimed.ac.id. Accessed on 16 December 2016.

Nursisto. 1999. Penuntun Pengarang. Yogyakarta: Adi Cita

Nur Aisyah. 2017. Pengembangan Instrumen Penilaian Tematik Berbasis Higher Order Thinking Skills Untuk Peserta Didik Kelas III Sekolah Dasar. Thesis. Lampung: Program Magister Pendidikan Guru Sekolah Dasar Universitas Lampung

Nation, I.S.P. and Macalister, J. 2010. Language Currilculum Design. New York: Routledge.

OECD. 2015. PISA 2015: Science competencies for tomorrow world volume 1: Analysis. Rosewood. Drive: OECD.

Permendikbud. 2014. Peraturan Menteri Pendidikan dan Kebudayaan Republik

Puerwanti, Endang. et.,al. 2008. Bahan Ajar Cetak Asesmen Pembelajaran SD. Direktorat Jendral Pendidikan Tinggi Departemen Pendidikan Nasional, Bandung. 9-39 hlm.

Rofiah, Emi., Nonoh Siti Aminah dan Elvin Yusliana Ekawati. 2013. Penyusunan Instrumen Tes Kemampuan Berpikir Tingkat Tinggi Fisika Pada Siswa SMP. Jurnal Pendidikan Fisika, Vol 1 (2): 17-22. Accessed on 24 March 2016.

Rubin, Jim \& Manikya Rajakaruna. 2015. Teaching and Assessing Higher Order Thinking in the Mathematics Classroom with Clickers. International Society of Educational Research, 10 (1): 37-51. iejme.com/makale_indir/88 Accessed on 1 September 2016.

Sani, Ridwan Abdullah. 2016. Inovasi Pembelajaran. Jakarta: Bumi Aksara . 2016. Penilaian Autentik. Jakarta: Bumi Aksara.

Setyosari, Punaji. 2012. Metode Penelitian Pendidikan dan Pengembangan. Kencana, Jakarta.

Sudijono, Anas. 2013. Pengantar Evaluasi Pendidikan. Jakarta: Rajawali Press. . 2008. Pengantar Evaluasi Pendidikan. Jakarta: Rajawali Press.

Sudjana, Nana. 2009. Penilaian Hasil Belajar dan Proses Belajar Mengajar. Remaja Rosdakarya, Bandung.

Sugiyono. 2014. Metode Penelitian Kulantitatif, Kualitatif, dan R\&D. ALFABETA, Bandung.

Suherman, E. 2003. Evaluasi Pembelajaran Matematika. JICA UPI, Bandung.

Suparno dan Yunus, Muhammad. 2004. Keterampilan Dasar Menulis. Jakarta: Universitas Terbuka.

Suprapranata, Sumarna. 2006. Analisis, Validitas, Reliabilitas dan Interpretasi Hasil Tes. PT. Remaja Rosda Karya, Bandung.

Suryawati. 2012. Kualitas Tes dan Hasil Belajar Matematika Siswa Kelas VIII SMP Negeri 9 Banda Aceh Tahun Pelajaran 2011/2012. Jurnal Peluang. Vol 1 No. 1 (online) Available in www.jurnal.unsyiah.ac.id/peluang/article/download/1300/1187. Accessed on 27 April 2017. 
Thorndike, R.L \& Hagen. 1977. Mesaurement and Evauation in Psychology and Education 4e. John Wiley \& Sons, Newyork.

Uno, Hamzah. 2012. Assesment Pembelajaran. Jakarta: Bumi Aksara.

Wardany, K., Sajidan, \& Murni R. (2015). Penyusunan Instrumen Tes Higher Order Thinking Skill Pada Materi Ekosistem SMA Kelas X. Seminar Nasional XII Pendidikan Biologi FKIP UNS 2015, Page 538-543. http://download. portalgaruda.org/article.php? article $=375337 \& v a l=4058 \&$ title $=$ Penyusunan $\% 20$ Instrum en\%20Tes\%20Higher\%20Order\%20Thinking\%20Skill\%20\%20Pada\%20Materi\%20E kosistem\%20SMA\%20Kelas\%20X. (Accessed on 7 August 2016)

Widana, I. 2017. Modul Penyusunan Soal Higher order thinking skills(HOTS). Jakarta: Direktorat Pembinaan SMA Direktorat Jenderal Pendidikan Dasar dan Menengah Departemen Pendidikan dan Kebudayaan.

Zira, Fatmaira. 2019. Pengembangan Instrumen Penilaian HOTS Pada Pembelajaran Teks Resensi Siswa Kelas XI SMA Negeri 5 Binjai. Medan. Indonesian Language and Literature Education Masters Program. Medan State University. 